\title{
Experiences of the Marginalized Women in America: Re-reading Maya Angelou's I Know Why the Caged Bird Sings(1970)
}

\author{
Birhan Assefie \\ English Language and Literature Department \\ Woldia University \\ Woldia, Ethiopia \\ birhanassefiesisay@gmail.com
}

\begin{abstract}
The aim of this article is to discover unnoted experiences of African-American women by taking Angelou's novel in focus. Experiences of marginalized women in African American haven't got sufficient attention. Their literature hasn't accorded the level it deserves. Specifically, autobiographies of black women have been ignored more severely than those of Americans. Maya Angelou, who won Pulitzer Prize for her first volume of autobiography-I Know Why the Caged Bird Sings, is one of the significant authors who wrote in addressing American subalterns'life. This article applies text based analysis and Black feminist literary theory. As a theoretical framework, it enables one to interrogate the relationships between self and selves of black women in America. Hence, race, gender and class issues were the general brands of black women's oppression. Racial prejudices against black women and the response to the injustices have been discussed based on the nature of resistance from helpless anger to outright protest. In addition, sexual abuse and segregation followed by ignorance and maternity have been analyzed as interlocked oppressions of black feminism. Although different kinds of oppression such as race, gender and class are
\end{abstract}


discussed, the article argues that Angelou's feminist portrayals are optimist. Thoughtful and kind as depictions show that the triple form of oppression of racism, sexism and classism can be resisted.

Key Terms: Afro-American, Black Feminism, Classism, Racism, Sexism, Subalterns,

1. Introduction

In the world, every nation has its own literature though some of them remain unknown due to hegemonic influence of dominant nations. Literatures of colored people have been given less emphasis while they themselves have been reading and studying works of white world. Black-Americans' literature has been neglected from American literary history for a long period of time. Literary works of Black women Americans have gotten the worst treatment considered as incompetent to different white made literary canons.

African-American literature is an ingredient of American literature that is produced, as the name implies, by Black Americans. The genre traces its origin to the slave narratives (Trudier Harris in, Mario Azevedo [2005]). It is continuing today with crafted Black authors such as Toni Morrison, Alice Walker, Maya Angelou and Walter Mosley; and they are ranked along with the top writers in the United States. Some of the themes and issues explored in African-American literature are the depiction of experiences of marginalized women. They also point to the role of African-American women within the larger American society, culture, racism, slavery, and inequality.

The position of African-Americans in American society has changed over the centuries from at least explicit marginalization into implicit one. As their place altered, the focus of their literature also changed. Before the American Civil War, African-American literature first and foremost paid attention on the topic of slavery, as indicated by the subgenre of slave narratives. According to Tyson (2006), at the turn of the 20th century, books by authors such as W.E.B. Dubois and Booker T. Washington discussed whether to 
tackle or calm racialist attitudes in the United States. During the American Civil Rights movement, authors such as Richard Wright and Gwendolyn Brooks wrote about issues of racial segregation and Black Nationalism. Today, African-American literature has become acknowledged as a fundamental component of American literature. The most important ground for the wide prevalence of this brand of literature is the nature of resistance depicting the experience of the marginalized. The term 'marginalized' is an umbrella term covering the whole marginalized society, but in the present article, it takes into account only the female writing and the female experience.

The stories of African-American writers have gained momentum in world literature. Voss asserts that "The Black power movement is gaining momentum and more AfricanAmerican women are expressing themselves in writing" (Norine Voss [in Judith Spector], 1986: 53). African American authors have started writing extensively on a variety of themes, especially their experience in America, Jamaica, and Britain.

As far as autobiography is concerned, it is a recent phenomenon with works like Frederick Douglass' Narrative of the Life of Frederick Douglass: An American Slave, Written by Himself (1845), Harriet Wilson's Our Nig (1859) and Harriet Jacobs' Incidents in the Life of A Slave Girl (1860) (Harris, 2005). Maya Angelou produced an autobiography, which is similar to that famous Douglass autobiographical work in its techniques of storytelling and plot development, in 1969. In the text, she applies the first-person narrative device so well that readers believe the novel is indeed the historical life story of its author. This and other literary voices of a critic about of quality of male or female African American author such as: theme development, characterization make Angelou's work fictional. Therefore, throughout the paper, the work has been referred as an autobiographical fiction or novel. Including the novel under study, African-American fictional autobiography roots in the oral tradition and in the African-American slave narrative. 
Though, it is said that African-American literature gets better attention now, it is yet to be granted the place it deserves in learning materials and college curricula. If not, it is difficult to bring the desired change in the society. Patterson (1968) says in similar fashion in the introduction part of his book,

And it is a sad fact that graduates of our finest institutions of higher learning leave their campuses without any knowledge of American history as it really is. These are the people who head, for the most part, the social and economic institutions in our country. And if they are not aware, how can we expect the man in the street to change his attitudes? (xvii)

Even the world community wouldn't change the image of Black-American literature and history. If the important theorists and commentators in literature rarely mention works by Afro-American writers, what is the average graduate student to think but that no such works exist or, if they do exist, that they are peripheral and unworthy of serious analysis. Therefore, beyond an exploration of Black feminine experiences, the paper aims to show the quality and real nature of African-American literature.

2. The Life of Maya Angelou

Maya Angelou was born on April 4, 1928, in St. Louis, Missouri, growing up in rural Stamps, Arkansas, with her brother, Bailey. She lived with her religious grandmother, who owned a general store. She attended public schools in Arkansas and California, and became San Francisco's first female streetcar conductor. Later she studied dance with Martha Graham and drama with Frank Silvera, and went on to a career in theater.

During the early 1960s, Angelou lived in Egypt, where she was the associate editor of The Arab Observer in Cairo. During this time, she also contributed articles to The Ghanaian Times and was featured on the Ghanaian Broadcasting Corporation Programming in Accra. During the mid-1960s, she became assistant administrator of the School of Music 
and Drama at the University of Ghana. She was the feature editor of the African Review in Accra from 1964 to 1966 . During this time she served as northern coordinator for the Southern Christian Leadership Conference at the request of Dr. Martin Luther King (Cudjoe, 1990). As a matter of nature, she gets aged as she is 84 years old. Maya Angelou lives in America now.

3. Major works of Maya Angelou

Although, Angelou began her literary career as a poet, she is well known for her five autobiographical works, which depict sequential periods of her life. I Know Why theCaged Bird Sings (1969) is about Marguerite Johnson and her brother Bailey growing up in Arkansas. It chronicles Angelou's life up to age sixteen, providing a child's view of the confusing world of adults. Although her grandmother instilled pride and confidence in her, her self-image was shattered when she was raped at the age of eight by her mother's boyfriend. Angelou was so devastated by the attack that she refused to speak for approximately five years. I Know Why the Caged Bird sings concludes with Angelou having regained self-esteem and caring for her newborn son, Guy. In addition to being a sharp account of an African-American girl's coming-of-age, this work affords insights into the social and political tensions of the 1930s. This volume is unique from others because it recounts the life experiences of a black girl's life, challenges and resistance in her early period of being a woman. The researcher chose it as it enables to study life and way of resistance to become a woman. Her stories trace the foundations of her identity as a twentieth-century American Black woman. Angelou has been praised for the rich and insightful prose of her narratives and what many observers feel is an indispensable record of Black experience. In her own words "If growing up is painful for the Southern Black girl, being aware of her displacement is the rust on the razor that threatens the throat," she wrote in the book "It is an unnecessary insult" (Angelou, 1969: 4). 
Her next autobiographical work, Gather Together in My Name, (1974) covers the period immediately after the birth of her son Guy and depicts her heroic struggle to care for him as a single parent. Her third volume, Singin' and Swingin' and Gettin' Merry Like Christmas (1976) describes Angelou's stage introduction and concludes with her return from the international tour of Porgy and Bess. The forth one, The Heart of A Woman (1981), portrays the mature Angelou becoming more comfortable with her creativity and her success. The fifth and the last volume, All God's Children Need Traveling Shoes (1986), recalls her four-year stay in Ghana, and its dominant theme is motherhood (Bader, 2004).

In her writings, the author is concerned with the question of what it means to be Black and female in America. Her development as a story writer is based on certain social forces which attack the Black woman with unusual intensity. According to Cecil \& Kelly (1998), it eventually becomes a fit and a substitute for a deeper look.

Commenting on Angelou's autobiographical writings, O'Neale wrote that one of the author's overall achievements is the elevation of the Black female in literature.

One who has made her life her message and whose message to all aspiring Black women is the reconstruction of her experiential 'self,' is Maya Angelou. With the wide public and critical reception of I Know Why the Caged Bird Sings in the early seventies, Angelou bridged the gap between life and art, a step that is essential if Black women are to be deservedly credited with enormous and creative feat of noneffacing survival (61).

By expressing herself, Angelou has tried to uncover sufferings of Black women in her times. She cried loud against racism, sexism and classism in her autobiographies, and she became a model black woman artist in the late $20^{\text {th }}$ century.

Cudjoe similarly commented that Angelou's autobiographies rescue not only her personal history, but the collective history of all Black women. Maya Angelou expressed 
specific concerns of Black girls in America. By giving rise for the new and unfamiliar genreautobiographical fiction-Angelou keeps the very nature of African-American literature. Hence, she contributed much in developing the genre and portraying marginalized female experiences.

Angelou commented to Claudia Tate in Black Women Writers at Work on the special importance of images for Black women. As she herself implemented in I Know Why the Caged Bird Sings, image making is essential for Black women writers since they are found in the area where considered as minority group. She said it is boring to always see males and whites on the stage. There should be equal participation of Black women. Angelou also described the awareness and responsibility she feels in providing images for Black women.

\section{Black Feminism}

There is no only post-colonial theory and no one critic can perhaps stand for, or articulate for, the post-colonial critical field. Out of the multitude of theories found under postcolonial theory, feminist theory is prominent. Even feminism is a broad area where various types of it are found. Among these, Black feminism is the perfect theory from which African-American women's fictional autobiography can be approached. Though the matter is severe with Black women writers, all post-colonial women writers explore their own cultural specificities in their literary works" (Katrak, 1996).

Black feminist literary perspective is quite suitable to study the experience of Black women in America. Unlike white feminism, it takes special aspects of the Black community into account. Black women's question relies not only on sexual rather on racial and class oppression. According to Katrak, "Racism along with sexism is important analytic categories within Third World feminisms, as are also the interesting categories of class, color, nation, without which one cannot undertake a satisfactory analysis of Third World women." (237) For Third World women, feminist struggles aspire for the full pride of 
women along with men.

As explained earlier under 3.6., the presence of male domination for a long period of time makes women to stand up for their rights against men and men-made rules and cultures under the shade of feminism. According to Leglistizin and Ross (1976), "Women in every country western or not western, industrialized or rural, modern and premodern are underutilized ... denied access to positions of prestige and power..." (7). Therefore, to keep away from the problem, various theories have been developed under feminism though still arguments are available on them. The dominant argument against the popular feminist literary theory is the inadequacy of the theory to be representative of all women writers in the world. It is exclusively made for white middle class women.

As Ketu H. Katrak in Bruce King (1996) attributes:

"Today, it is commonly accepted that feminisms are historically, culturally, and geographically specific. This doesn't eliminate hegemonic tendencies in certain schools of feminism that continue to be Universalist, perhaps not overtly, but subtly, and hence more dangerously, and in spite of the challenges of Black and Third World feminist theorists." (236)

By showing the failure of white feminism to incorporate the voices of Black women writers, Black feminists showed the varied position of their case as it is associated with oppression of women based on their color and sex. Hence, Black feminism becomes appropriate brand of feminism to deal with Black women's experiences. In brief, it is foolishness to try to analyze works of Black women based on western feminism instead of Black feminist theoretical framework that enables to address special aspects of Black women such as racism, sexism and classism.

Until the 1980s, western feminists assumed that their aspects of feminism work for the whole women in the world. They thought that there are common forms of oppression of 
women. Nevertheless divisions among feminists depend on nationality, race, language and religion occurred. Hence, it disproved the project of western feminists. Prominent scholars who exposed the limitedness of western feminism include famous Black feminists such as: Dubois, 1978; Davis, 1982; Rich, 1986 and Anzaldua and Morga, 1981.

Black feminists and critics of post-colonialism have made mere investigations of the racism and ethnocentricism at the heart of white feminisms. bell hooks argues that:

All too frequently in the women's movement it was assumed one could be be free of sexist thinking by simply adopting the appropriate feminist rhetoric; it was further assumed that identifying oneself as oppressed freed one from being an oppressor. To a grave extent such thinking prevented white feminists from understanding and overcoming their own sexist-racist attitudes towards Black women. They could pay leap service to the idea of sisterhood and solidarity between women but at the same time they dismiss Black women (bell hooks, 1984: 8-9).

White feminism has no any perfect support from any of other feminisms. For instance, they don't understand as there is power relation between them and Black feminists, and the central point of western feminism is highly problematic for Black feminism. The primary source of oppression for white feminists is men, but Black feminists raise a number of sources for their oppression such as race, gender and class. In other words, assumptions at the heart of white feminism don't reflect the experience of Black women. This is well stated by McEwan (2009) that

Western feminists have been criticized for universalizing their own particular perspectives as normative, essentializing women in the south as tradition-bound victims of timeless, patriarchal cultures, and reproducing the colonial discourses of main stream, 'male-stream' scholarship...the tendency of western feminism to theorize difference in universalizing ways is also problematic (99). 
As many African and other colored scholars say, colonization doesn't totally end rather it continues in different forms. Though in the current postmodernism period, there is hybridity of cultures, still the domination of western based culture is visible. "The implications of western feminists writing about women outside their own cultural milieu must be considered in the context of the global hegemony of western scholarship; in other words, western domination of the production, publication, distribution and consumption of information and ideas(Ibid: 104)." Hence, the basic influence of the women's movement came from demanding for the inclusion of race, class and gender as determinant factors as women's oppression.

Black Feminist scholars accused white feminists as they failed to address the issues of race, class and gender as determinants for women's oppression. And they question white feminists' act of universalizing their feminist ideas to all women of the world. This idea is strengthened by Lorde states as follows:

Mainstream feminist thought reflected the hardship of white women and specifically middle to high income bracketed ones. This narrowly defined movement was dominated by white feminist thinkers whose main assertion was that there was equality in women's oppression. But the crucial point here is the extent of the oppression experienced by different women i.e. it did not include the issue of class, race, religion and sexual orientation. Although a Black and a white woman are both victimized by the institutionalized form of sexism, a Black woman has to live with the added complexity of class and race issue(Lorde, 1989:1).

bell hooks in her book-Feminist theory - From Margin to Center (1984)-recounts a debate in her classroom where she argued against her white classmates the most important determinant for the origin of domination, is skin color then follows gender. She stresses her argument by attacking the women's liberation movement by claiming that the movement has 
not only been prepared on a fine platform, it first and foremost called interest to issues pertinent chiefly to white women with class privilege. She adds by saying "We need a theory mapping thought and strategy for a mass based movement, theory that would examine our culture from a feminist standpoint rooted in understanding of gender, race and class" (xii).

\section{Discussion}

\subsection{Racial Prejudice and Negro Resistance}

Arkansas is a racist area divided between Black and white, male and female. Angelou uses metaphor of a bird struggling to escape its cage, described in Paul Laurence Dunbar's poem, as a central image throughout I Know Why the Caged Bird Sings. As she reveals via her works, the caged bird sings of freedom bound by the cage of race, gender and class. The novel represents Angelou's imprisonment resulting from racism and oppression. Angelou demonstrates, through her involvement with the Black community of Stamps, as well as her presentation of vivid and realistic racist characters and the offensiveness of Southern white attitudes toward African-Americans, her developing understanding of the system for surviving in a racist society. Her fictional autobiography contains a sequence of lessons about resisting oppression. The sequence she describes leads Angelou, as the protagonist, from helpless rage and resentment to forms of subtle resistance.

Angelou displays that Momma's approach to handle racism serves as a base for actively protesting and combating racism. Momma is portrayed as a practical person whose patience, courage, and silence ensured the survival and success of those who came after her. For example, Maya breaks the race barrier to become the first Black street-car operator in San Francisco, and responds assertively to the demeaning treatment by her white employer Mrs. Cullinan. In addition, Angelou's description of the strong and unified Black community of Stamps demonstrates how African-Americans challenge oppressive institutions to refuse to go along with racism. The author demonstrates how she, as a Black child, develops her 
racial hatred, common in the works of many contemporary Black novelists and autobiographers. At first Maya wishes that she could become white, since growing up Black in white America is unsafe; later she gets rid of her self-hatred and embraces a strong racial identity.

The nature of Negro resistance in the story is mainly provided in two forms: subtle resistance and active protest. The story line of I Know Why the Caged Bird Sings shows these two forms of confrontation against racism respectively. It begins with passive protest against maltreatment of whites followed by overt objection from Blacks against racial acts.

\subsubsection{Disrespect}

As Angelou calls 'powhitetrash' girls mock Maya's grandmother by posing the physical appearance of the big Black old mother as an ape. They continue the act of mocking up to a hand stand of one of them without any cover of the body in front of Momma. Momma is the respected religious mother who owns the only Black owned Store, and she is the woman who borrows money to the poor people without color barrier during the Great Depression. So, how moral just to tease such kind of person? In fact, she gets this treatment since she is Black and Black nothing else.

They came finally to stand on the ground in front of Momma. At first they pretended seriousness. Then one of them wrapped her right arm in the crook of her left, pushed out her mouth and started to hum. I realized that she was aping my grandmother. Another said, 'Naw, Helen, you ain't standing like her. This here's it." Then she lifted her chest, folded her arms and mocked that strange carriage that was Annie Henderson. Another laughed, “Naw, you can't do it. Your mouth ain't pooched out enough. It's like this" (Ibid., p. 29).

Maya observes the scene from the place where Momma told her to be. She becomes emotional against the white children who show rudeness and crudity, and she wishes to 
stone them. The event causes Maya to react with helpless anger and humiliation, but through the response of Momma to the girls, Maya learns there can be a better and more effective way to respond.

At first, Maya's reaction to the "powhitetrash" girls is anger, resentment, embarrassment, defenselessness. When the girls ape her grandmother's posture, Maya weeps, thinks of getting her uncle's rifle, and wants to throw lye and pepper on them and to scream at them. When they leave and Momma politely calls good-bye to them, Maya's rage peaks:

[S]he stopped singing and said, “'Bye, Miz Helen, 'bye, Miz Ruth, 'bye, Miz Eloise.” I burst. A firecracker July-the-Fourth burst. How could Momma call them Miz? The mean nasty things. Why couldn't she have come inside the sweet, cool store when we saw them breasting the hill? What did she prove? And then if they were dirty, mean and impudent, why did Momma have to call them Miz? (Ibid., p. 31-32)

However, Maya realizes that her grandmother has achieved something and won it. Maya learns a lesson that there is a more effective strategy for reacting to racism and segregation than rage and indignation, a strategy of fine resistance. Here, the response to the racist children is subtle resistance that doesn't harm life, liberty or property.

\subsubsection{Disheartenment}

The act of undermining the Black students' future happened at the time of Maya's $8^{\text {th }}$ grade graduation by the white man invited as a guest speaker. There is an abuse by the white person, when the speaker tells the Black audience of all the improvements which the white schools will receive-improvements that far exceed the few planned for the Black school. The white man named as Mr. Edward Donleavy from Texarkana gives quite racist speech in front of the Black crowd during the commencement address of the graduation. 
He said that he had pointed out to people at a very high level that one of the firstline football tacklers at Arkansas Agricultural and MechanicalCollege had graduated from good old LafayetteCountyTraining School. Here fewer Amen's were heard. Those few that did break through lay dully in the air with the heaviness of habit. He went on to praise us. He went on to say how he had bragged that "one of the best basketball players at Fisk sank his first ball right here at LafayetteCountyTraining School.” ...The white kids were going to have a chance to become Galileos and Madame Curies and Edisons and Gauguins, and our boys (the girls weren't even in on it) would try to be Jesse Owenses and Joe Louises (Ibid., p.174).

The white man disheartens and annoys the Black crowd including students and their parents together with school administrators by saying that Black students will hired in labor oriented jobs, and they luck mental brilliance so that they couldn't be like the known scientists.

Maya's first response of humiliation and anger happens; "Then I wished that Gabriel Prosserand Nat Turnerhad killed all whitefolks in their beds" (Ibid., p. 176). The anger doesn't remain limited to the young Maya rather it gets shared now by her community in the hall; “...the proud graduating class of 1940 had dropped their heads" (Ibid., p.175). Then there is the action on the part of a member of the Black community - Henry Reed's improvised leading the audience in "Lift Ev'ry Voice and Sing" (Ibid., p. 178). The song is called 'Black National Anthem' and every Black in the hall sings it. In the same vain to the response against powhitetrash girls, the song avoids an out-and-out conflict with the white oppressor and permits the Black community to feel its dignity and superiority; "We were on top again. As always, again. We survived" (Ibid., p. 179). Here the response is not only noticed from the central character but also from the Black community. The resistance is still 
not exactly an outright protest and it still avoids open confrontation, since the white insulter has left and does not hear the singing.

\subsection{Discrimination}

One of the greatest abuses occurs when Stamps' white and only dentist - to whom Maya's grandmother had lent money, interest-free and as a favor-refuses to treat Maya's severe toothache, telling Maya and Momma,

“Annie?" "Yes, sir, Dentist Lincoln.” He was choosing words the way people hunt for shells. “Annie, you know I don't treat nigra, colored people." "I know, Dentist Lincoln. But this here is just my little grandbaby, and she ain't gone be no trouble to you ..." "Annie, everybody has a policy. In this world you have to have a policy. Now, my policy is I don't treat colored people... My policy ..." He let go of the door and stepped nearer Momma. The three of us were crowded on the small landing. "Annie, my policy is I'd rather stick my hand in a dog's mouth than in a nigger's." He had never once looked at me. He turned his back and went through the door into the cool beyond (Ibid., p. 183-184).

What makes the discrimination not to treat Maya the worst thing of racism and rudeness is that the dentist is the man who received much money at the time of Great Depression from Maya's grandmother-Mrs. The maltreatment is not limited to Maya rather it goes to Mrs. Henderson, who is the richest Black in the area. The seriousness of the pain of Maya's toothache and the openhandedness of Mrs. Henderson do not bother the arrogant white dentist to say no for their inquiry since they are not white rather they are Black. Similarly, with the case when powhitetrash girls tease Momma, now also Mrs. Henderson warns her grand-daughter to leave the room and wait outside to save the child from racist events happened which may be dangerous for the growing child. This shows how Momma, as expected, is role model of her grand-daughter. 
The kind of resistance is different from the rest of passive ones in that here, through the italicized text, it is shown that Momma directly confronts the dentist and finally orders him to leave the town sooner.

'I didn't ask you to apologize in front of Marguerite, because I don't want her to know my power, but I order you, now and herewith. Leave Stamps by sundown." “Mrs. Henderson, I can't get my equipment ...” He was shaking terribly now. "Now, that brings me to my second order. You will never again practice dentistry. Never! When you get settled in your next place, you will be a vegetarian caring for dogs with the mange, cats with the cholera and cows with the epizootic. Is that clear?" The saliva ran down his chin and his eyes filled with tears. "Yes, ma'am. Thank you for not killing me. Thank you, Mrs. Henderson” (Ibid., p. 185).

The only part of the novel presented in stream of consciousness tells us what Maya thinks in her mind at the time when she was waiting for her Momma outside of the building. Momma threatens the white dentist in front of him which is unusual to her. Actually, this happens in the mind of Maya who fantasizes her grand-mother bothers her enemy. The actual event happened to the dentist is that momma collects an interest of the money she gave him before. The italicized passage reveals what Maya wishes her grandmother could do to the racist dentist.

Maya noticed no open confrontation from her Momma against the racist whites, and she knows that is out of momma's philosophy. The act created by Maya herself highlights that subtle resistance is not enough as an overall strategy for responding to racist oppression. On the other hand, the fantasy passage anticipates the kind of outright confrontations between oppressed Black and racist oppressor. Although it is only a fantasy, it is the first instance in the novel of a Black person openly confronting a racist white, and thus is the first hint that such confrontation is a possibility. 


\subsection{Naming}

Our name is an essential part of our identity, if someone deliberately changes our name; it is a lack of respect for our self. Maya's name gets changed easily by a white woman from 'Marguerite' to 'Mary' without consent of her. The act is totally unkind for the poor Maya, who sympathizes to the woman.

Maya first began working as a domestic-in-training for Mrs. Cullinan, she felt nothing but forgiveness for her mistress. Mrs. Cullinan was fat and could not have any children because she had no organs. Even when she pronounced Angelou's name incorrectly from 'Marguerite' in to 'Margaret', Maya smiled and felt sorry for her.

However, her feelings get changed when one of Mrs. Cullinan's friends suggests that she calls the girl Mary, as this was shorter and easier to say than Marguerite. "Well, that may be, but the name's too long. I'd never bothe myself. I'd call her Mary if I was you'" (Ibid., p. 104). Mrs. Cullinan received the woman's advice, and proclaimed that Angelou was 'Mary' from now on.It shows the lack of respect white mistresses have for their servants, who are considered as inferior just because they are Black. So, it is natural that Maya didn't like being called out of her name. First it meant the white does not respect her, and then it reminds her of the slavery times when Blacks were named on the will of their masters.

Black servant, Maya, is called out of her name at the time when she is working for Mrs. Cullinan,

...she called me by the wrong name. Miss Glory and I were washing up the lunch dishes when Mrs. Cullinan came to the doorway. "Mary?" Miss Glory asked, "Who?" Mrs. Cullinan, sagging a little, knew and I knew. "I want Mary to go down to Mrs. Randall's and take her some soup. She's not been feeling well for a few days." Miss Glory's face was a wonder to see. "You mean Margaret, ma'am. Her name's Margaret." "That's too long. She's Mary from now on (Ibid., p. 105). 
Mrs. Cullinan gives new name to Marguerite as 'Mary' that is not really related to the original name. The boss provides the reason behind changing the name of her servant as the first name is quite long to call and better to change it with the short one. Mrs. Cullinan's act is a violation of Marguerite's identity since she is just Black girl.

Marguerite, the main character of the story, is courageous to perform what she needs to do. Her own name that was given to her by her parents, is just now so easily changed by the white woman, makes her very angry. She feels that she was just robbed of something important, her name. Even though, she is just a young girl, she doesn't want to tolerate such mistreatment. Her inner dignity and pride arise and push her to forget about her need of money and job. She frightfully feels that her opinion might never be valued. That is when she decides to change all that once and for all. Marguerite feels that it is crucial to make a statement. She breaks her employer's favorite piece "china from Virginia” (Ibid., p. 107).

Maya disliked Mrs. Cullinan for changing her name, and it is really painful to let a white woman rename you for her convenience. Following her brother's advice, she dropped and broke Mrs. Cullinan's favorite dishes; a fish-shaped casserole dish and green glass coffee cups on purpose. She rebelled against her. "When I heard Mrs. Cullinan scream, "Mary!" I picked up the casserole and two of the green glass cups in readiness. As she rounded the kitchen door I let them fall on the tiled floor" (Ibid., p. 107). Here, it shows how Marguerite expresses her internal feelings without any hesitation. After calling her a few discriminatory names, Mrs. Cullinan finally called Maya by her correct, but still mispronounced name: Margaret. Maya, with her active protest against the injustice, deserves her identity at least by getting her favorite name. This is the actual open confrontation against racism next to the hint in the scene of the white dentist.

Maya Angelou skillfully presents two stories to compare and to make a reader clear more with the idea. While the act shown above is a huge act against the oppressor, the Black 
girl named as Glory shows opposite position with regard to the change of name.

Miss Glory had a fleeting second of feeling sorry for me. Then as she handed me the hot tureen she said, "Don't mind, don't pay that no mind. Sticks and stones may break your bones, but words ... You know, I been working for her for twenty years." She held the back door open for me. “Twenty years. I wasn't much older than you. My name used to be Hallelujah. That's what Ma named me, but my mistress give me 'Glory,' and it stuck. I likes it better too." I was in the little path that ran behind the houses when Miss Glory shouted, "It's shorter too." For a few seconds it was a tossup over whether I would laugh (imagine being named Hallelujah) or cry (imagine letting some white woman rename you for her convenience). My anger saved me from either outburst. I had to quit the job, but the problem was going to be how to do it (Ibid., p. 106).

Maya becomes really ashamed of Glory who does not mind to be renamed by the white lady. This incident is provided to make a contrast of feeling created to Maya and Glory. Maya becomes angry with the act of the boss, whereas Glory enjoys the new name since it is, as she says, 'short'. Though the Black girl is victim of the attack, she does not realize it is an insult. The relationship between Glory and Mrs. Cullinan is well, glory seems to have accepted the fact that Black people are under the control of white section. Even though Mrs. Cullinan renames her Glory, Glory accepts it. However, Angelou did not appreciate being treated like she was an object that could be given a new name whenever its owner pleased, but she also pitied her mistress, and she conveyed her feelings by using an angry tone of writing. She acts against the white women directly in front of her by distracting the precious properties.

In the same chapter of the novel, there are other incidents of racism. When Maya and Glory serve Mrs. Cullinan, it is strictly forbidden to share any materials even drinking ones 
with the white family members. The two Blacks have separate glasses to drink from and their glasses were kept in separate shelves. "I had a glass to drink from, and it sat with Miss Glory's on a separate shelf from the others" (Ibid., p. 103). This is an act of racism that shows the misrepresentation of Blacks as sub-humans who shouldn't be served equally with whites the so called humans.

One of the noticeable experiences that happened to Maya in the novel is standing up for what you believe in and not allowing anyone to take advantage of you. Angelou demonstrates the racist habit of renaming African-Americans, as shown when her white employer insists on calling her Mary. Angelou describes the employer's renaming as the "hellish horror of being 'called out of his name'" (Ibid., p. 106). Maya understands that she is being insulted and rebels by breaking Mrs. Cullinan's favorite dish.

\subsection{Outright Protest}

In San Francisco, it was a dream to see a Black woman being streetcar conductor before Maya Angelou's success to be the first Negro girl street car conductor. In fact, it is not the interest to challenge the institution rather a need to survive that leads Maya to apply for the job. But, eventually, it brings another interest beyond securing her income not to pause her education. At the beginning, Maya knows from her mother that it is impossible to be hired as a conductor being a Black girl. "To her question of what I planned to do, I replied that I would get a job on the streetcars. She rejected the proposal with: 'They don't accept colored people on the streetcars"” (Ibid., p. 257).

However, she continues to struggle for the job. When the white secretary of the San Francisco street-car company repeatedly frustrates her attempts for a job interview, Maya is at first persuaded not to take it personally:

The incident was a recurring dream, concocted years before by stupid whites and it eternally came back to haunt us all. The secretary and I were like Hamlet and Laertes 
in the final scene, where, because of harm done by one ancestor to another, we were bound to duel to the death. Also because the play must end somewhere, I went further than forgiving the clerk, I accepted her as a fellow victim of the same puppeteer (Ibid., p. 260).

But then Maya decides that the rejections, which have everything to do with her race, also have everything to do with her personally, and this is because her personal identity and her racial identity cannot be entirely separated: "The whole charade we had played out in that crummy waiting room had directly to do with me, Black, and her, white" (Ibid., p. 260). After a long and tiring bargain with the white receptionist, she becomes the first ever Black girl streetcar conductor in San Francisco. "[O]n a blissful day I was hired as the first Negro on the San Francisco streetcars" (Ibid., p. 262). San Francisco is a place where there was serious racism. "A story went the rounds about a San Franciscan white matron who refused to sit beside a Negro civilian on the streetcar, even after he made room for her on the seat. Her explanation was that she would not sit beside a draft dodger who was a Negro as well" (Ibid., p. 207-208). Attaining the street-car conductor's job becomes not only a victory for civil rights, as a result, but also a personal victory for Maya's sense of self. The active resistance and outright protest, that is Maya's persisting and breaking the 'color line'of the San Francisco street-car company.

\subsection{Sexual Abuse}

The young Maya is raped at the age of eight by her mother's boyfriend-Mr. Freeman. Maya is abused many times by whites since she is Black, but now she gets hurt by a Black man since she is a woman. As she herself mentioned at the very beginning of the novel, it is quite doomed to be woman in racist and sexist society of America. Black women in America face double jeopardy from the white and the male group but I add classism as the third form of oppression that black women receive. 
Angelou's depiction of rape exposes the real suffering of many Black American women. There is one more way that men exploit women by sexual mistreatment. This is what happens to the poor young Maya by the man who as the same time owns her mother for his sexual practice. Mr. Freeman is probably initiated by the absence of strict rules that guard Black women in the country at that time. It is noticed that he is released after a very short period of time for his severe crime from jail. That is why one of the uncles of Maya, though not clearly mentioned in the novel, murders him to get justice by his own.

Mr. Freeman deceives Maya by pretending as if he were playing with her without any sexual desire.

"We was just playing before." He released me enough to snatch down my bloomers, and then he dragged me closer to him. Turning the radio up loud, too loud, he said, "If you scream, I'm gonna kill you. And if you tell, I'm gonna kill Bailey." I could tell he meant what he said. I couldn't understand why he wanted to kill my brother. Neither of us had done anything to him. And then. Then there was the pain. A breaking and entering when even the senses are torn apart. The act of rape on an eight-year-old body is a matter of the needle giving because the camel can't. The child gives, because the body can, and the mind of the violator cannot (Ibid., p. 79).

Mr. Freeman threatens to kill Maya's brother Bailey if she tells anyone concerning the rape. After Maya lies during Freeman's trial, stating that the rape was the first time he touched her improperly, Freeman is murdered by one of Maya's uncles and Maya sees her words as a source of death. As a result, she resolves never to speak to anyone other than Bailey. Angelou connects the violation of her body and the devaluation of her words through the depiction of her self-imposed, five-year-long silence. As Angelou later stated: 
In those moments I decided that although Bailey loved me he couldn't help. I had sold myself to the Devil and there could be no escape. The only thing I could do was to stop talking to people other than Bailey. Instinctively, or somehow, I knew that because I loved him so much I'd never hurt him, but if I talked to anyone else that person might die too. Just my breath, carrying my words out, might poison people and they'd curl up and die like the Black fat slugs that only pretended. I had to stop talking (Ibid., p. 84).

Maya chooses not to speak after her rape because she is afraid of the destructive power of words.

Maya's rape demonstrates how as a Black woman, she is violated as she moves from childhood to adolescence. The act of rape happens to another girl at the time when Joe Louis had boxing race with his white counterpart. During the process of the race when Louis fails, many events take place around the Black community. Among these, rape to the ladies is the serious one. One more woman ambushed and raped (Ibid., p. 131). In general, it can be taken as a depiction of burden and a demonstration of the manner in which the Black female is violated. The writer stated her own experience to demonstrate the complexities of rape. She also wants to prevent it from happening to someone else, so that anyone who had been raped might gain understanding and not blame herself for it.

\subsection{Segregation}

It is well known that African-Americans living in the southern United States were treated with abhorrence by the majority of white people. The nation was divided by segregation - a formal policy in which Black people weren't allowed to attend good schools, get high-paying jobs, live in valuable houses or receive proper medical treatment for their diseases. They weren't even allowed to sit among white people on public buses, or drink from the same water sources, as they were considered to be unworthy of equality. They weren't slaves anymore since the Civil War brought an end to that inhumanity and social 
injustice, but they were still thought to be sub-human. In short, the policy of segregation did everything within its power to ensure that Black people remained poor and ignorant, and most importantly, below white people on the hierarchy of power and privilege.

A light shade had been pulled down between the Black community and all things white, but one could see through it enough to develop a fear-admiration-contempt for the white "things"- white folks' cars and white glistening houses and their children and their women. But above all, their wealth that allowed them to waste was the most enviable (Ibid., p. 47-48).

Angelou captures Maya's childlike observations about what makes white people different. Her fixation on clothing as a sign of difference also refers back to the incident in church when she suddenly realizes that her fairy-tale dress is really an old, faded white woman's hand-me-down. The church is the place where segregation takes place, for there were only blacks in the church where Maya was attending sermon.

Stamps, Arkansas, suffers so thoroughly from segregation and Maya's world is so completely trapped in the Black community that she often finds it hard to imagine what white people look like. They appear to her more like supernatural ghosts with strange powers and magnificent possessions than as Black human beings.

Maya's fellow men and women meet at her grandmother's store to listen to the live commentary of the boxing race between the Black Joe Louis and the white counterpart.

My race groaned. It was our people falling. It was another lynching, yet another Black man hanging on a tree. One more woman ambushed and raped. ... This might be the end of the world. If Joe lost we were back in slavery and beyond help. It would all be true, the accusations that we were lower types of human beings. Only a little higher than the apes (Ibid., p. 131). 
Maya crowds around the Store's radio with the rest of the community to listen to Joe Louis defend his world heavyweight boxing title. The Black community lives separately far from white's district. The Black people meeting at Mrs. Henderson's Store to share their psychological hope with the metaphor of the fight between their hero and the white one. The public victory of the Black Joe Louis proves to Blacks in the Store that they are the most powerful people in the world and enables them to live another day with strength and vigor in the face of oppression. Even though, some Blacks from rural areas fail to go back to their home in the night since walking on the rood too far is quite dangerous for their life since the white representative is defeated on the same day.

Segregation is noticed with unfair schooling service provided for particularly Black women and for Blacks in general when compared with the rest of white students in America. As it is mentioned by Angelou, There are separate schools or colleges for Blacks and whites. At the time when Maya attends training, she notices that Black girls had a less privileged education than white girls. "Admittedly the training was not the same. While white girls learned waltz and sit gracefully with a tea cup balanced on their knees, we were lagging behind, learning the mid-Victorian values with very little money to indulge them" (Ibid., p. $101)$.

When Maya attends her schooling in LafayetteCountyTraining School, the school of Blacks, up to grade 8 , she observes the school quite inferior to the 'White school'. The school where she graduated grade eight lacks many necessary things including teaching aid materials and qualified teachers.

Unlike the white high school, LafayetteCountyTraining School distinguished itself by having neither lawn, nor hedges, nor tennis court, nor climbing ivy. Its two buildings (main classrooms, the grade school and home economics) were set on a dirt hill with no fence to limit either its boundaries or those of bordering farms. 
There was a large expanse to the left of the school which was used alternately as a baseball diamond or a basketball court. Rusty hoops on the swaying poles represented the permanent recreational equipment, although bats and balls could be borrowed from the P. E. teacher if the borrower was qualified and if the diamond wasn't occupied. Over this rocky area relieved by a few shady tall persimmon trees the graduating class walked. ... Only a small percentage would be continuing on to college — one of the South's A \& M (agricultural and mechanical) schools, which trained Negro youths to be carpenters, farmers, handymen, masons, maids, cooks and baby nurses (165).

Hence, segregation, as revealed in the novel, is one of the dominant experiences of Black women in America. It has been the common thing to be surprised to see a Black woman in white's school, cafeteria, hotel and sometimes road.

\section{Conclusion}

The fictional autobiography by Maya Angelou is a specimen of resistance literature. The article focuses on the exploration of feminine experiences throughout the plot of the novel that enabled the researcher to discover the experiences of resistance and courage in the face of adversity. As Black feminists firmly argue, Black girl in America experiences triple oppression of race, sex and class. As Angelou depicts skillfully in her novel, racial prejudice happens to Maya at her Grade 8 graduation by the white guest, sexual abuse happens to Maya by her mother's Black boyfriend and economic problems happen to Maya all the way through her young life in the segregated Arkansas.

As shown in the analysis part of the paper, the novel directly or indirectly deals with the power of women to survive and shape their own future despite hardships. The lesson gained out of the current study is that failure is inevitable but it is quite necessary to lift one up again. Angelou, in a crafted manner, tries to make visible the relationships between Black 
and white people via the experiences of the Black girl in Southern America.

As is known, power is still in the hands of white people and Black people are still largely dependent on them. In the USA the struggle for equality, particularly in the southern states, has been long and difficult, from the civil rights movement of the 1950s and 1960s to the political debates still going on today. 


\section{References}

Primary Material

Angelou, M. (1969). I Know Why the Caged Bird Sings. New York: Random House.

Secondary Materials

Bader, P. (2004). African-American Writers. New York: Facts on File, Inc.

Cecil, K. \& Kelly H.(1998). Maya Angelou. Pembroke: University of North Carolina. Retrieved on January 20, 2012 from http://www.joyofquotes.com/inspirationalquotes-by-author.html

Cudjoe, S. R. (1990) “Maya Angelou: The Autobiographical Statement Updated." In Reading Black, Reading Feminist: A Critical Anthology. (Ed.) Henry L. G., Jr. New York: Meridian.

Harris, T. (2005).African-American Literature: A Survey. In Azevedo, M. (ed.). Africana Studies: A Survey of Africa and The African Diaspora ( $3^{\text {rd }}$ edn.). Durham: Carolina Academic Press.

hooks, b. (1984). Feminist Theory From Margin to Center. Cambridge: Sound End Press.

Katrak, K. H. (1996). Post-colonial Women Writers and Feminisms. In King, B. (ed.). New National and Post-colonial Literatures: An Introduction (p. 230-267).Oxford: Clarendon Press.

Leglistizin, B. \& Ross, R. (1976).Women in the World: Comparative Study. Oxford: Clio Books.

Lorde, A. (1989). In A. R. Chandra TalpadeMohanty (Ed.), Third World Women and the Politics of Feminism. Indiana: IndianaUniversity Press. 
McEwan, C. (2009). Postcolonialism, feminism and development: intersections and dilemmas. Progress in Development Studies, 1(2), 93-11. Retrieved on January 25, 2012 from http://pdj.sagepub.com

O'Neale, S. (2004). The Perception of Black Women. In Bloom's Guides: Comprehensive Research and Study Guides. Google Book Search. Retrieved on January 20, 2012.

Patterson, L. (ed.). (1968). International Library of Negro Life and History: An Introduction to Black Literature in America from 1746 to the Present. New York: Publishers Company, Inc.

Tyson, L. (2006). Critical Theory Today: A User Friendly Guide. (2 ${ }^{\text {nd }}$ edn.). New York: Routledge.

Voss, N. (1986). Saying the Unsayable: an Introduction to Women's Autobiography. In Spector, J. (ed.), Gender Studies: New Directions in Feminist Criticism (p. 218-33). Ohio: BrowlingGreenStateUniversity Popular Press. 